ernment-dependent sector with the simultaneous rise of public programs may be interpreted as public "substituting for" or "crowding out" government-dependent programs. These developments thus signal the sharpening of privatepublic distinctiveness in short-cycle provision across Europe.

\section{Higher Education in Albania: The Never Ending Challenge}

\section{BLendi KajSIU}

Blendi Kajsiu is an independent researcher with a PhD from the University of Exeter, UK. E-mail: kajsiu@yahoo.com. This article appeared in a different format in Stepping Into a New Era, edited by A. Glass (European Association for International Education, 2014 Conference Conversation Starter).

Since the collapse of communism in I99I, Albanian $\checkmark$ higher education has been torn between massification and a lack of adequate funding. During the last io years alone, the number of students enrolled in Albanian universities has almost tripled. Yet, Albanian governments did not match such rapid increase in the number of students with an equal increase in the higher education budget. As of today (20I5), Albania remains one of the countries that spends the smallest proportion of its GDP, around 0.6 percent, on higher education. This means that while higher education has become more accessible to larger numbers, its quality has suffered dramatically.

During the past 25 years, the challenge of accommodating a growing demand for higher education in the context of limited financial resources has drawn three distinct responses by different Albanian governments. During the first decade of Albanian transition (early i990s to early 2000s), the main objective was to open and increase the number of state-owned higher education institutions (HEIs). During the second decade, from 2005 until 2013, when the Democratic Party was in power, the main government strategy was to stimulate private HEIs that would accommodate the additional demand for higher education-which state institutions could not meet. Since 2013, when the Socialist Party returned to power, the new reform has aimed to merge the state and the private sectors, transforming all HEIs into not-for-profit institutions that will be partly financed by the state and partly through private means.
Expanding Public Higher Education, 1995-2005

Faced with a growing demand for higher education, Albanian governments initially responded by expanding the state-funded higher education sector. Existing HEIs outside the capital Tirana were transformed into universities. Between I992 and I998, six such universities were created. By 2005 , state-funded universities had opened in all the major cities in Albania.

While these measures helped increase the number of students enrolled in higher education institutions, they also undermined the quality of higher education. The constant increase in student numbers in public universities, without a corresponding increase in state funding, resulted in a serious drop in quality of teaching and research. Faced with overcrowded classrooms, lecturers were burdened with too much teaching, which undermined their ability to carry out research. As a result of financial restrictions, many public universities started hiring and attracting cheaper faculty dedicated exclusively to teaching. In many cases, departments did not meet even the minimal standards required by law concerning student-faculty ratios or faculty qualifications.

\section{Expanding the Private Sector, 2005-2013: The Market Will SAVE Us!}

During the period 2005-2013, when the Democratic Party came to power, almost 50 new private HEIs were licensed and the number of students in the private sector increased I5 fold. The government limited itself to accrediting HEIs without attempting to rank or evaluate them. By 20I4, Albania had one of the highest numbers of private HEIs per million inhabitants in Europe.

\section{While these measures helped increase the number of students enrolled in higher education institutions, they also undermined the quality of higher educa- tion.}

From 2005 to 2013 , the ruling Democratic Party turned a blind eye to the declining quality of higher education, both in the public and the private sectors. It constantly increased admission quotas in the public sector, without a corresponding increase in state funds, while licencing numerous new private universities. The government ignored major scandals in some of the most corrupt private HEIs, which were openly selling Albanian university degrees, including to citizens from neighboring countries such as 
Italy, who spoke no Albanian.

The decreasing quality of the public sector also brought down the quality of some of the best private-sector institutions. Once the public universities completely opened up their doors without additional resources, further lowering their standards, the pool of students from whom private universities could choose and charge fees decreased both quantitatively and qualitatively. As a result, some serious private institutions began to cut costs by lowering facultystudent ratios and other academic standards.

\section{The Socialist Reform: Merging State and Private Insti- TUTIONS}

Once the Socialist Party came to power on June 2013, it promised a new law on higher education that would bring it up to European standards. As part of this process, the current administration started a general inspection of the higher education sector. This culminated in August 20I4, with the closure of I7 private and 8 public HEIs, which were found in breach of basic government regulations. The government will also conduct an evaluation of the remaining institutions in collaboration with the British Quality Assurance Agency for Higher Education.

Despite the above positive measures, the Socialist reform faces major limitations, as long as the state lacks the necessary resources to properly finance higher education. The new law allows public universities to raise funds by increasing tuition fees, on the premise that the state cannot provide much additional funding. It also stipulates that private universities can receive state funding, if they are transformed into not-for-profit organizations. The distinction between state and private universities is therefore blurred.

A major transformation of higher education that is not backed by increased state funding does not bode well for the future. Just like earlier governments, the current government has not shown a clear commitment to properly funding higher education. During its two years in power (2013-20I5), there has been very little additional funding for the higher education sector-even though when in opposition, the Socialists recognized that the sector was severely underfunded by the state. It seems unlikely that the situation will change in the near future, given that on February 20I4 the government signed a US\$330 million loan with the International Monetary Fund that called for reduced public spending. Under these circumstances, the challenge of higher education in Albania remains intact.

\section{Challenges for Romanian Higher Education}

\section{Ligia DeCA}

Ligia Deca is a doctoral researcher at the University of Luxembourg. E-mail: ligia.deca@uni.lu. This article appeared in a different format in Stepping Into a New Era, edited by A. Glass (European Association for International Education, 2014 Conference Conversation Starter).

$\mathrm{R}$ omania is a relatively recent member of the European Union (EU), since 2007, and a NATO member. Its geostrategic options seem thus to be clearly defined and one of few generally accepted issues. Reforms in the field of higher education have been seen as part of a larger national agenda for reintegration in the Western democratic world. However, in the past 25 years, Romanian higher education policies have rarely been based on sound data collection, impact assessments, or inclusive consultations within the system. Discussing new versions of the national education law seems to be a political obsession for every new minister, without any reflection on what really needs to change policy wise.

Judging by the influence of international norms on domestic reforms, one can say that Romanian higher education has gone through three main development phases: the post-I989 "international actors" phase, in which a shift from previous models was heavily influenced by the World Bank, the OECD, the European Commission, and UNESCO-CEPES; the phase of implementation of the Bologna process, which started in 2004-2005 with major legal overhauls aimed at increasing the "readability" of the Romanian higher education system (three cycles: ECTS, Diploma Supplement, quality assurance); and the recent phase of global competitiveness, influenced mainly by the rankings and excellence discourse, but also by demographic challenges.

Romania's decision-making environment is rather unstable -20 education ministers tried to define a new vision for education in the past 25 years. This brought a fastchanging decision-making environment, heavy bureaucracy, and incoherent legislation-except for occasional inspired policy decisions.

\section{Double Discourse}

As part of recent planning efforts for the EU 2OI4-2020 financial exercise, Romania had to submit a number of strategies that were supposed to include both national priorities and accompanying actions for: the tertiary education sector; early school leaving; and lifelong learning. These strategies were designed in 20I3-20I4 with the assistance of the World Bank and submitted to the European Com- 